\title{
Pengaruh Model Problem Based Learning (PBL) terhadap Kemampuan Komunikasi Matematika Peserta Didik Kelas X SMA Negeri 3 Maros
}

\author{
Nur Rahmaeda', Dedy Setyawan ${ }^{2}$ \\ ${ }^{1}$ Pesantren Raodatul Athfal Yadi Bontocina \\ ${ }^{2}$ Universitas Muslim Maros \\ 1 edha1698@gmail.com \\ ${ }^{2}$ dedynuny50@gmail.com
}

\begin{abstract}
ABSTRAK
Penelitian ini merupakan penelitian eksperimen yang bertujuan untuk mengetahui pengaruh dari penerapan model Problem Based Learning terhadap kemampuan komunikasi matematika peserta didik kelas X SMA Negeri 3 Maros. Jenis penelitian ini adalah penelitian kuantitatif dengan The Nonequivalent Control Grup Design, dimana terdapat dua kelas, yaitu kelas eksperimen dan kelas kontrol. Kelas eksperimen diajar menggunakan model Problem Based Learning, dan kelas kontrol menggunakan model pembelajaran konvensional. Populasi dalam penelitian ini adalah peserta didik kelas X SMA Negeri 3 maros dengan pengambilan sampel dilakukan secara acak masing-masing sebanyak 30 peserta didik dalam satu kelas. Sampel dalam penelitian ini adalah peserta didik pada kelas X MIPA 5 sebagai kelas eksperimen dan X MIPA 6 sebagai kelas kontrol. Pengumpulan data menggunakan tes kemampuan komunikasi matematika berupa pretest dan posttest yang telah divalidasi oleh ahli. Data hasil penelitian ini dianalisis secara deskriptif dan inferensial dengan uji normalitas dan uji homogenitas sebagai uji prasyarat analisis dan uji t sebagai uji hipotesa. Hasil analisis deskriptif menunjukkan bahwa rata-rata posttest pada kelas kontrol adalah 61,50 dengan standar deviasi 11,956 sedangkan rata-rata posttest pada kelas eksperimen adalah 77,60 dengan standar deviasi 7,219. Berdasarkan uji t, diperoleh nilai $p 0,000<1 / 2 \alpha=0,025$ yang menunjukkan adanya perbedaan dari kemampuan komunikasi matematika kelas kontrol dan kelas eksperimen, sehingga dapat disimpulkan bahwa ada pengaruh dari penerapan model Problem Based Learning terhadap kemampuan komunikasi matematika peserta didik kelas X SMA Negeri 3 Maros.
\end{abstract}

Kata Kunci: Pengaruh, Problem Based Learning, Kemampuan Komunikasi Matematika

\begin{abstract}
This research is an experimental research that aims to determine the effect of the application of the Problem Based Learning model to the mathematical communication skills of class $X$ students of SMA Negeri 3 Maros. This type of research is quantitative research with The Nonequivalent Control Group Design, where there are two classes, namely the experimental class and the control class. The experimental class was taught using the Problem Based Learning model, and the control class used a conventional learning model. The population in this study were students of class X SMA Negeri 3 Maros with random sampling of 30 students each in one class. The sample in this study were students in class X MIPA 5 as an experimental class and X MIPA 6 as a control class. Data collection using mathematics communication skills test in the form of pretest and posttest which has been validated by experts. The results of this research were analyzed descriptively and inferentially with the normality test and homogeneity test as a prerequisite test for analysis and t test as a hypothesis test. The results of the descriptive analysis showed that the average posttest in the control class was 61.50 with a standard deviation of 11.956 while the average posttest in the experimental class was 77.60 with a standard deviation of 7.219. Based
\end{abstract}


on the $t$ test, $p$ value obtained $0,000<1 / 2 \alpha=0.025$ which indicates a difference in the mathematical communication skills of the control class and the experimental class, so it can be concluded that there is an influence from the application of the Problem Based Learning model to the mathematical communication skills of students in class X SMA Negeri 3 Maros.

Keywords: Influence, Problem Based Learning, Mathematical Communication Ability.

\section{A. PENDAhuluan}

Pendidikan memiliki peran penting dalam kehidupan manusia. Melalui pendidikan manusia dapat mengembangkan potensi yang dimilikinya dan menambah pengetahuan baru. Manusia membutuhkan pendidikan yang bermutu karena melalui pendidikan bermutu akan lahir pribadi yang berkualitas dan mampu membangun masyarakat kea rah yang lebih baik.

Perbaikan mutu pendidikan menjadi hal yang menarik untuk selalu ditelaah khususnya pendidikan matematika. Dalam dunia pendidikan pelajaran matematika perlu diberikan kepada semua peserta didik mulai dari sekolah dasar untuk membekali peserta didik dengan kemampuan berpikir logis, analitis, sistematis, kritis, dan kreatif, serta kemampuan bekerjasama. Kompetensi tersebut diperlukan agar peserta didik dapat berkembang menjadi manusia yang berkualitas dan mampu menjawab tantangan zaman yang selalu berubah.

Menurut Ruseffendi (dalam Hodiyanto, 2017) bagian terbesar dari matematika yang dipelajari peserta didik disekolah tidak diperoleh melalui eksplorasi matematik, tetapi melalui pemberitahuan. Kenyataan di lapangan juga menunjukkan demikian, bahwa kondisi pembelajaran yang berlangsung di kelas membuat peserta didik menjadi pasif. Lebih lanjut (Hodiyanto, 2017) mengungkapkan bahwa berbagai hasil penelitian menunjukkan bahwa merosotnya pemahaman matematik peserta didik di kelas antara lain karena: (1) dalam mengajar pendidik mencontohkan pada peserta didik bagaimana menyelesaikan soal; (2) peserta didik belajar dengan cara mendengar dan menonton pendidik melakukan matematik, kemudian pendidik memecahkannya sendiri; (3) pada saat mengajar matematika, pendidik langsung menjelaskan topic yang akan dipelajari, dilanjutkan dengan pemberian contoh dan soal untuk latihan. Kondisi pembelajaran yang disebutkan di atas berakibat tidak berkembangnya kemampuan komunikasi matematis peserta didik.

Kemampuan komunikasi matematis peserta didik adalah kemampuan peserta didik dalam mengekspresikan gagasan-gagasan, ide-ide, dan pemahamannya tentang konsep dan proses matematika yang mereka pelajari. Kemampuan komunikasi matematika meliputi: penggunaan bahasa matematika yang diwujudkan dalam bentuk lisan, tulisan, atau visual: (2) penggunaan representasi matematika yang diwujudkan dalam bentuk tulisan atau visual: dan (3) kejelasan presentasi, yakni menginterpretasikan ide-ide matematika, menggunakan istilah matematika atau notasi 
matematika dalam merepresentasikan ide-ide matematika, serta menggambarkan hubunganhubungan atau pendekatan matematika.

Indikator kemampuan komunikasi matematis menurut Ansari (dalam Yanti \& Basri, 2017) yaitu dapat (1) menggambarkan situasi dari suatu persoalan ke dalam gambar, tabel, diagram, maupun grafik; (2) mengungkapkan dan menjelaskan ide-idenya tentang suatu masalah secara tulisan; (3) menggunakan ekspresi dan symbol-simbol matematika secara tepat.

Untuk mengatasi masalah-masalah tersebut, pendidik memiliki peran penting dalam upaya meningkatkan kemampuan komunikasi matematis peserta didik. Oleh karena itu, perlu diadakan perubahan model pembelajaran yang biasa dilakukan oleh pendidik dengan pembelajaran yang menyenangkan dan dapat diterima oleh peserta didik. Model pembelajaran yang dipilih harus dapat mengembangkan kemampuan peserta didik untuk menginterpretasikan suatu permasalahan ke dalam bentuk matematika dengan baik. Salah satu alternatif model tersebut dalah Problem

\section{Based Learning.}

Nurhadi (dalam Hadijah, 2018) menyatakan bahwa Problem Based Learning adalah suatu model pembelajaran yang menggunakan masalah dunia nyata sebagai konteks bagi peserta didik untuk belajar berpikir kritis dan keterampilan pemecahan masalah, serta untuk memperoleh pengetahuan dan konsep yang esensial dari materi pelajaran. Selain itu,
Margetson mengemukakan bahwa kurikulum PBL membantu untuk meningkatkan perkembangan keterampilan belajar sepanjang hayat dalam pola piker yang terbuka, reflektif, kritis, dan belajar aktif. Kurikulum PBL memfasilitasi keberhasilan memecahkan masalah, komunikasi, kerja kelompok, dan keterampilan interpersonal dengan lebih baik dibandingkan pendekatan yang lain (Rusman, 2013)

\section{B. METODOLOGI PENELITIAN}

Jenis penelitian ini adalah kuasi eksperimen dengan metode kuantitatif. Penelitian ini membandingkan dua kelompok, yaitu kelas eksperimen dan kelas kontrol. Kelas eksperimen diberikan perlakuan berupa pembelajaran dengan model Problem Based Learning sedangkan kelas kontrol menggunakan pembelajaran konvensional.

Rancangan penelitian ini berbentuk desain kelompok nonequivalent (The Nonequivalent Control Group Design). Sebagaimana disajikan pada tabel berikut:

Tabel 1. The Nonequivalent Control Group Design

\begin{tabular}{ccc}
\hline 01 & $\mathrm{X} 1$ & $\mathrm{O} 2$ \\
\hline $\mathrm{O3}$ & - & $\mathrm{O} 4$ \\
\hline \multicolumn{3}{c}{ Sumber: (Sugiyono, 2016) }
\end{tabular}

Keterangan:

01 : Tes yang diberikan pada pretest di kelas eksperimen.

O2: Tes yang diberikan pada pstest di kelas kontrol.

O3 : Tes yang diberikan pada pretest di kelas eksperimen. 
O4 : Tes yang diberikan pada posttest di kelas kontrol.

X1 : Perlakuan pada kelas eksperimen berupa model Problem Based Learning.

" - ": Perlakuan pada kelas kontrol berupa pembelajaran konvensional.

Populasi dalam penelitian ini adalah peserta didik kelas X SMA Negeri 3 Maros yang terdiri dari 6 kelas yaitu dapat dilihat pada tabel dibawah ini:

Tabel 2. Jumlah Siswa Kelas X MIPA SMAN 3 Maros

\begin{tabular}{cc}
\hline Kelas & Banyaknya Siswa \\
\hline X MIPA 1 & 32 \\
\hline X MIPA 2 & 31 \\
\hline X MIPA 3 & 30 \\
\hline X MIPA 4 & 31 \\
\hline X MIPA 5 & 30 \\
\hline X MIPA 6 & 30 \\
\hline Jumlah & 154 \\
\hline
\end{tabular}

Sampel pada penelitian ini adalah peserta didik kelas X Mipa 5 dan kelas X mipa 6 SMAN 3 maros yang masing-masing berjumlah 30 peserta didik dengan teknik pengambilan sampel adalah simple random sampling.

Penelitian ini dilaksanakan dengan tiga tahap yaitu tahap persiapan, tahap pelaksanaan, dan tahap pengolahan data.

\section{Tahap Persiapan}

a. Orientasi lapangan berupa observasi di sekolah dan kelas (tempat penelitian).

b. Penyusunan rencana pelaksanaan pembelajaran (RPP) serta bahan ajar untuk kelas eksperimen dan kelas kontrol.

c. Penyusunan instrument tes yang akan digunakan dalam penelitian. d. Uji kelayakan instrumen penelitian.

\section{Tahap pelaksanaan}

a. Melaksanakan pretest pada kelas eksperimen dan kelas kontrol.

b. Melaksanakan pembelajaran dengan model problem based learning pada kelas eksperimen dan model pembelajaran konvensional pada kelas kontrol.

c. Melaksanakan posttest pada kelas eksperimen dan kelas kontrol.

\section{Tahap Pengolahan Data}

a. Mengolah dan menganalisis hasil data yang diperoleh dari masing-masing kelas.

b. Penarikan kesimpulan dari hasil olah data dan analisis data.

Teknik pengumpulan data yang dilakukan dalam penelitian ini adalah observasi dan teknik pustaka. Sumber data dalam penelitian ini adalah peserta didik. Jenis data yang akan diperoleh adalah data kuantitatif yang diambil dari tes kemampuan komunikasi matematis berupa pretest dan posttest.

Cara pengambilan data kemampuan komunikasi matematis akan diambil dengan memberikan tes kepada peserta didik sebelum dan setelah pembelajaran. Bentuk tes yang digunakan dalam penelitian ini adalah tipe uraian yang terdiri dari 3 soal dengan indikator penilaian yaitu menggambar (drawing), ekspresi matematika (mathematical expression), dan menulis (written text). Tes yang diberikan pada setiap kelas baik soal-soal untuk pretest dan posttest sama. Sebelum penyusunan tes kemampuan komunikasi matematis, terlebih 
dahulu dibuat kisi-kisi soal tes kemampuan komunikasi matematis.

Pedoman penskoran kemampuan komunikasi matematis siswa terdapat pada tabel 3.

Tabel 3. Pedoman Penskoran Kemampuan Komunikasi Matematis Siswa.

\begin{tabular}{|c|c|c|c|}
\hline Skor & Menggambar & Ekspresi Matematika & Menulis \\
\hline 0 & \multicolumn{3}{|c|}{$\begin{array}{l}\text { Tidak ada jawaban, kalaupun ada hanya memperlihatkan tidak memahami konsep sehingga } \\
\text { informasi yang diberikan tidak memiliki arti. }\end{array}$} \\
\hline 1 & $\begin{array}{l}\text { Hanya sedikit dari } \\
\text { gambar, tabel, atau } \\
\text { diagram yang benar }\end{array}$ & $\begin{array}{l}\text { Hanya sedikit dari pendekatan } \\
\text { matematika yang benar }\end{array}$ & $\begin{array}{l}\text { Hanya sedikit dari } \\
\text { penjelasan yang benar }\end{array}$ \\
\hline 2 & $\begin{array}{l}\text { Membuat gambar, } \\
\text { diagram, atau tabel } \\
\text { namun kurang lengkap } \\
\text { dan benar }\end{array}$ & $\begin{array}{l}\text { Membuat pendekatan matematika } \\
\text { dengan benar namun salah dalam } \\
\text { mendapatkan solusi }\end{array}$ & $\begin{array}{l}\text { Penjelasan secara } \\
\text { matematis masuk akal } \\
\text { namun hanya sebagian } \\
\text { yang lengkap dan benar }\end{array}$ \\
\hline 3 & $\begin{array}{l}\text { Membuat gambar, } \\
\text { diagram, atau tabel } \\
\text { secara lengkap dan } \\
\text { benar }\end{array}$ & $\begin{array}{l}\text { Membuat pendekatan matematika } \\
\text { dengan benar, kemudian } \\
\text { melakukan perhitungan dan } \\
\text { mendapatkan solusi secara lengkap } \\
\text { dan benar. }\end{array}$ & $\begin{array}{l}\text { Penjelasan secara } \\
\text { matematis tidak tersusun } \\
\text { secara logis atau terdapat } \\
\text { sedikit kesalahan bahasa }\end{array}$ \\
\hline 4 & - & - & $\begin{array}{l}\text { Penjelasan secara } \\
\text { matematis masuk akal } \\
\text { dan jelas serta tersusun } \\
\text { secara sistematis }\end{array}$ \\
\hline $\begin{array}{l}\text { Skor } \\
\text { Max }\end{array}$ & 3 & 3 & 4 \\
\hline
\end{tabular}

Untuk menganalisis data dari hasil penelitian digunakan teknik analisis statistik deskriptif dan statistik inferensial sebagai berikut:

\section{Statistik Deskriptif}

Metode statistik deskriptif digunakan untuk mendeskripsikan data, misalnya untuk mengetahui gambaran hasil belajar peserta didik (Arikunto: 2006). Nilai yang umumnya dihitung dalam statistika deskriptif untuk mengetahui gambaran hasil belajar peserta didik adalah mean, median, modus, nilasi maksimum, nilai minimum, simpangan baku, variansi dan skor Z (skor baku).
2. Statistik Inferensial

Statistika inferensial digunakan untuk menguji hipotesis penelitian. Dalam penelitian ini digunakan analisis statistika independent Sample T-Test untuk menguji hipotesis penelitian. Namun sebelum dilakukan uji hipotesis, terlebih dahulu dilakukan uji prasyarat yaitu uji normalitas dan uji homogenitas.

\section{HASIL PENELITIAN}

\section{Analisis Statistik Deskriptif}

Deskripsi hasil penelitian ini dimaksudkan guna memberikan gambaran umum mengenai 
hasil pretest dan posttest peserta didik kelas kontrol dan kelas eksperimen yang disajikan pada uraian berikut:

\section{a. Deskripsi Tes hasil kemampuan komunikasi} matematika pretest dan posttest kelas kontrol.

Tabel 4. Rekapitulasi Hasil Tes Kemempuan Komunikasi Matematika Pretest dan Posttest Kelas Kontrol.

\begin{tabular}{llrr}
\hline & Pretest & Posttest \\
\hline $\mathrm{N}$ & Valid & 30 & 30 \\
\hline & Missing & 0 & 0 \\
\hline Mean & 40.77 & 61.50 \\
\hline Median & 39,50 & 59,00 \\
\hline Modus & 37 & 55 \\
\hline Std daviation & 8,336 & 11,956 \\
\hline Variance & 69,495 & 142,956 \\
\hline Range & 39 & 46 \\
\hline Minimum & 17 & 40 \\
\hline Maximum & 56 & 86 \\
\hline Sum & 1223 & 1845 \\
\hline
\end{tabular}

Berdasarkan hasil descriptive frequency, maka diketahui bahwa rata-rata hasil tes kemampuan komunikasi matematika dari data posttest pada kelas $\mathrm{X}$ mipa 6 tanpa menerapkan model pembelajaran PBL adalah 61,50. Adapun nilai tengah data tersebut adalah 59,00 dengan nilai paling sering muncul adalah 55 dan standar deviasi 11,956.

b. Deskripsi Tes hasil kemampuan komunikasi matematika pretest dan posttest kelas kontrol.

Tabel 5. Rekapitulasi Hasil Tes Kemampuan Komunikasi Matematika Kelas Eksperimen.

\begin{tabular}{llrr}
\hline & & Pretest & Posttest \\
\hline $\mathrm{N}$ & Valid & 30 & 30 \\
\hline & Missing & 0 & 0 \\
\hline Mean & & 41,03 & 77,60 \\
\hline
\end{tabular}

\begin{tabular}{lrr}
\hline & Pretest & Posttest \\
\hline Median & 39,50 & 79,00 \\
\hline Modus & 37 & 79 \\
\hline Std daviation & 8,696 & 7,219 \\
\hline Variance & 75,620 & 52,110 \\
\hline Range & 39 & 25 \\
\hline Minimum & 17 & 65 \\
\hline Maximum & 56 & 90 \\
\hline Sum & 1231 & 2328 \\
\hline
\end{tabular}

\section{Analisis Statistik inferensial}

Uji statistic inferensial yang digunakan pada penelitian ini adalah uji paired sample t test dan uji independent sample $t$ test. Namun sebelum melakukan uji tersebut, perlu dilakukan uji prasyarat yakni uji normalitas dan homogenitas.

\section{a. Uji Normalitas}

Uji normalitas berfungsi untuk mengetahui apakah data berdistribusi normal atau tidak. Uji ini menjadi prasyarat pertama sebelum dilakukan uji hipotesis. Dengan taraf signifikansi (a) yang digunakan adalah 0,05. Data dikatakan berdistribusi normal apabila nilai sig. > 0,05 dan tidak berdistribusi normal apabila nilai sig. < 0,05 . Berikut adalah output dari uji normalitas pada data posttest kelas kontrol dan kelas eksperimen yang menggunakan SPSS:

Tabel 6. Hasil Uji Normalitas Pretest dan Posttest Kelas Kontrol dan Kelas Eksperimen.

\begin{tabular}{llrcrrrrr}
\hline \multicolumn{1}{c}{ Kelas } & \multicolumn{4}{c}{ Kolmogorov- $^{c}$ Smimov $^{\mathbf{a}}$} & \multicolumn{4}{c}{ Shapiro-Wilk } \\
& & Statistic & Df & Sig. & Statistic & Df & Sig. \\
Kemampuan & Pretest Eksperimen &, 148 & 30 &, 092 &, 957 & 30 &, 265 \\
Komunikasi & Posttest &, 110 & 30 &, $200^{*}$ &, 963 & 30 &, 366 \\
Matematika & Eksperimen & & & & & & \\
& Pretest Kontrol &, 150 & 30 &, 081 &, 956 & 30 &, 251 \\
& Posttest Kontrol &, 154 & 30 &, 067 &, 944 & 30 &, 118 \\
\hline
\end{tabular}

Berdasarkan output dari Test of Normality, yang dilihat pada Shapiro Wilk diperoleh nilai 
signifikansi untuk pretest kelas kontrol sebesar 0,251 dan posttest kelas kontrol sebesar 0,118 sedangkan nilai signifikansi untuk pretest kelas eksperimen sebesar 0,256 dan posttest kelas eksperimen sebesar 0,336. Karena nilai signifikansi untuk kelas kontrol dan kelas eksperimen lebih besar dari 0,05 maka dapat disimpulkan bahwa data pretest dan posttest kelas kontrol dan kelas eksperimen berdistribusi normal. Karena semua data telah berdistribusi normal selanjutnya dilakukan uji paired sample $t$ test.

\section{b. Uji Homogenitas}

Uji homogenitas merupakan salah satu syarat (bukan syarat mutlak) dalam uji independent sample t test. Dalam penelitian ini uji homogentias digunakan untuk mengetahui apakah varians data posttest kelas eksperimen (model Problem based Learning) dan data post test kelas kontrol (konvensional) bersifat homogen atau tidak.

Dengan taraf signifikansi yang sama, yakni 0,05 maka pedoman pengambilan kesimpulannya adalah jika nilai signifikansi (sig) Based on Mean > 0,05 maka variansi data adalah homogeny dan jika nilai signifikansi (sig) Based on mean $<0,05$ maka variansi data adalah tidak homogeny. Dari proses analisis uji homogenitas dengan SPSS diperoleh output sebagai berikut:

Tabel 7 Hasil Uji Homogenitas

\begin{tabular}{lrrrrr} 
& Levene Statistic & df1 & & df2 & \multicolumn{2}{c}{ Sig. } \\
\hline Nilai & Based on Mean & 6.669 & 1 & 58 & .012 \\
\hline
\end{tabular}

Berdasarkan output test of homogeneity diketahui bahwa nilai signifikansi (sig) Based on Mean adalah 0,012<0,05 sehingga dapat disimpulkan bahwa variansi data posttest kelas kontrol dan kelas eksperimen adalah tidak sama atau tidak homogeny (heterogen).

\section{c. Uji Hipotesis}

Untuk menjawab rumusan masalah yang pertama maka diperlukan uji paired sample $t$ test pada kelas eksperimen yang telah menerapkan model pembelajaran Problem Based Learning (PBL).

Tabel 8 Hasil Uji Paired Sample t Test Kelas Eksperimen

\begin{tabular}{|c|c|c|c|c|c|c|c|c|}
\hline & & \multicolumn{7}{|c|}{$\begin{array}{l}95 \% \text { confidance } \\
\text { interval of the } \\
\text { difference }\end{array}$} \\
\hline & & Mean & $\begin{array}{c}\text { Std. } \\
\text { Daviation }\end{array}$ & Lower & Upper & $\mathrm{T}$ & df & $\begin{array}{l}\text { Sig (2- } \\
\text { tailed) }\end{array}$ \\
\hline Pair 1 & $\begin{array}{l}\text { PreEkss- } \\
\text { postElks }\end{array}$ & $-36,567$ & 11,527 & $-40,871$ & $-32,375$ & $\begin{array}{l}-17 \\
375\end{array}$ & 29 & 0,000 \\
\hline Pair 2 & $\begin{array}{l}\text { Prekon- } \\
\text { PostKon }\end{array}$ & $-20,733$ & 15,922 & $-26,679$ & $-14,788$ & & 29 & 0,000 \\
\hline
\end{tabular}


Berdasarkan output pair 1 (sig) $<0,05$ maka dapat disimpulkan ada perbedaan kemampuan komunikasi matematika untuk pretest eksperimen dan posttest eksperimen dengan menggunakan model PBL. Berarti ada pengaruh diterapkannya model PBL terhadap kemampuan komunikasi matematika peserta didik kelas $X$ SMA Negeri 3 Maros.

Kemudian untuk menjawab rumusan masalah yang kedua yaitu "apakah ada perbedaan kemampuan komunikasi matematika peserta didik antara model Problem Based Learning (PBL) dengan model konvensional?" maka perlu dilakukan uji independent sample $t$ test yang dilakukan terhadap data posttest eksperimen (model PBL) dengan data posttest kelas kontrol (model konvensional).

Dengan kaidah pengambilan keputusan adalah jika nilai sig. (2tailed) $<1 / 2 \alpha$, maka Ho diterima yaitu tidak ada perbedaan kemampuan komunikasi matematika peserta didik pada kelas kontrol maupun kelas eksperimen. Sedangkan jika nilai sig. (2tailed) $>1 / 2 \alpha$ maka Ho ditolak atau Ha diterima yaitu ada perbedaan kemampuan komunikasi matematika peserta didik antara kelas kontrol dan kelas eksperimen. Taraf signifikansi yang digunakan adalah 0,05 maka 1/2 $\alpha$ adalah 0,025 .

Tabel 9. Hasil Uji Independent Sample t Test

\begin{tabular}{|c|c|c|c|c|c|c|c|c|}
\hline & & \multicolumn{7}{|c|}{ t-test for Equality of Means } \\
\hline & & \multirow[b]{2}{*}{$\mathrm{T}$} & \multirow[b]{2}{*}{$\mathrm{Df}$} & \multirow{2}{*}{$\begin{array}{l}\text { Sig. (2- } \\
\text { tailed) }\end{array}$} & \multirow{2}{*}{$\begin{array}{c}\text { Mean } \\
\text { Difference }\end{array}$} & \multirow{2}{*}{$\begin{array}{c}\text { Std. Error } \\
\text { Difference }\end{array}$} & \multicolumn{2}{|c|}{$\begin{array}{c}95 \% \text { Confidence } \\
\text { Interval of the } \\
\text { Difference }\end{array}$} \\
\hline & & & & & & & Lower & Upper \\
\hline \multirow[t]{2}{*}{ Nilai } & $\begin{array}{l}\text { Equal } \\
\text { variances } \\
\text { assumed }\end{array}$ & 6.314 & 58 & .000 & 16.100 & 2.550 & 10.996 & 21.204 \\
\hline & $\begin{array}{l}\text { Equal } \\
\text { variances } \\
\text { not } \\
\text { assumed }\end{array}$ & 6.314 & 47.663 & .000 & 16.100 & 2.580 & 10.972 & 21.228 \\
\hline
\end{tabular}

Karena uji homogenitas diketahui bahwa variansi data posttest kelas kontrol dan kelas eksperimen adalah tidak homogen maka pada tabel output independent sample $t$ test yang dilihat adalah Equal variance not assumed.

Berdasarkan output pada tabel independent sample $t$ test diketahui bahwa sig. (2-tailed) $0,000<0,025$ maka dapat disimpulkan bahwa
Ho ditolak atau Ha diterima. Hal ini sesuai dengan perbandingan $\mathrm{t}$ hitung dengan $\mathrm{t}$ tabel, dimana $t$ hitung yang diperoleh pada output diatas adalah 6,314 dan $t$ tabel pada derajat kebebasan (df) $=48$ dan taraf signifikansi 0,05 adalah 0,680 maka diketahui bahwa t hitung $>\mathrm{t}$ tabel $(6,314>0,680)$ dan sesuai dengan kaidah 
pengambilan keputusan bahwa, jika $\mathrm{t}$ hitung $>\mathrm{t}$ tabel maka Ho ditolak dan Ha diterima.

Hal ini berarti ada perbedaan nilai kemampuan komunikasi matematika pada peserta didik kelas eksperimen yang menggunakan pembelajaran dengan model PBL dengan kelas kontrol yang menggunakan pembelajaran konvensional atau penerapan model pembelajaran PBL memberikan pengaruh terhadap kemampuan komunikasi matematika peserta didik kelas X SMA Negeri 3 Maros.

\section{PEMBAHASAN}

Untuk mengetahui kondisi awal dari kemampuan komunikasi matematika peserta didik, pendidik memberikan tes awal (pretest) dengan materi yang telah ditentukan. Tes yang digunakan adalah tes uraian yang mengandung indikator kemampuan komunikasi matematika yang meliputi: Menulis, menggambar, dan ekspresi matematika.

Penerapan model Problem Based Learning (PBL) memberikan pengaruh positif terhadap kemampuan komunikasi matematika peserta didik. Pengaruh tersebut dapat dijelaskan oleh nilai rata-rata tes kemampuan komunikasi matematika yang diukur melalaui tes awal (pretest) sebelum peserta didik diberi perlakuan dan tes akhir (posttest) setelah peserta didik diberi perlakuan.

Nilai rata-rata peserta didik pada pretest adalah 41,03 kemudian nilai rata-ratanya meningkat menjadi 77,60 pada posttest di akhir pembelajaran. Pembelajaran dengan model PBL bertujuan untuk memudahkan pendidik dalam mengajar dan memudahkan peserta didik memahami materi dan latihan-latihan yang diberikan baik secara mandiri maupun kelompok. Pembelajaran dengan model PBL dapat melatih peserta didik untuk aktif dalam kegiatan pembelajaran, aktif bertanya dan mengemukakan pendapat maupun pengetahuan yang telah dipelajarinya di kelas

Hal yang lebih positif adalah peserta didik menunjukkan respon yang baik. Hal ini terlihat ketika peserta didik aktif menjawab dan mengerjakan latihan yang diberikan di depan kelas maupun pada saat kerja secara berkelompok. Peserta didik juga menunjukkan pemahaman konsep yang mendalam mengenai materi yang diberikan, kemampuan menjelaskan yang baik di depan kelas.

Hal ini sesuai dengan penelitian yang dilakukan (Sumunaringtiasih, 2017) mengenai pengaruh model Problem Based Learning (PBL) terhadap peningkatan komunikasi matematis siswa yaitu adanya peningkatan kemampuan komunikasi matematis peserta didik yang mengikuti PBL lebih tinggi daripada peningkatan kemampuan komunikasi matematis peserta didik yang mengikuti pembelajaran yang bukan PBL.

Hasil penelitian menunjukkan bahwa hasil analisis pada uji paired sample $t$ test adalah $0,000<0,05$ yang berarti Ho ditolak. Dari hal tersebut dapat dikatakan bahwa kemampuan komunikasi matematika peserta didik setelah di ajar dengan menggunakan model PBI mengalami peningkatan dan berpengaruh 
positif terhadap kemampuan komunikasi matematika peserta didik.

Kemudian uji independent sample $t$ test diperoleh nilai sig (2-tailed) sebesar 0,000 dengan taraf signifikansi yang digunakan adalah $1 / 2 \alpha=0,025$ dengan ketentuan jika nilai sig (2tailed) $<1 / 2 \alpha$ maka Ho ditolak dan Ha diterima jika sig (2-tailed) $>1 / 2 \alpha$. Adapun nilai sig (2tailed) yakni 0,000 0,025 maka Ho ditolak sehingga dari hal tersebut dapat dikatakan bahwa terdapat perbedaan kemampuan komunikasi matematika peserta didik kelas $\mathrm{X}$ pada kelas kontrol dan kelas eksperimen. Hal ini juga dapat dilihat melalui perbedaan rata-rata nilai pada kedua kelas tersebut.

Berdasarkan uraian diatas dapat disimpulkan bahwa pembelajaran dengan menerapkan model pembelajaran Problem based Learning (PBL) pada kelas X SMA Negeri 3 Maros dapat mempengaruhi kemampuan komunikasi matematika peserta didik.

\section{E. PENUTUP}

\section{Kesimpulan}

Berdasarkan pembahasan hasil penelitian maka dapat ditarik kesimpulan sebagai berikut:

a. Kemampuan komunikasi matematika peserta didik kelas X Mipa 5 SMA Negeri 3 Maros yang menerapkan model pembelajaran Problem Based Learning memperoleh ratarata sebesar 77,60 lebih tinggi dibandingkan dengan rata-rata hasil tes kemampuan komunikasi matematika peserta didik kelas $\mathrm{X}$ Mipa 6 SMA Negeri 3 Maros yang tidak menerapkan model pembelajaran PBL sebesar 61,50 .

b. Penerapan model pembelajaran Problem Based Learning memberikan pengaruh terhadap kemampuan komunikasi matematika peserta didik kelas X SMA Negeri 3 Maros, yang didasarkan pada hasil uji paired sample $t$ test. Dan terdapat perbedaan kemampuan komunikasi matematika peserta didik kelas X SMA Negeri 3 Maros pada kelas kontrol dan kelas eksperimen, yang didasarkan pada hasil uji independent sample t test.

\section{Saran}

Untuk meningkatkan kemampuan siswa dalam menyelesaikan soal-soal matematika maka diharapkan siswa SMA menerapkan model pembelajaran Problem Based Learning dengan melibatkan siswa secara aktif menyelesaikan masalah matematika dalam konteks kehidupan nyata. Sebagai tindak lanjut penggunaan model pembelajaran Problem Based Learning pada saat proses pembelajaran berlangsung kepada guru senantiasa memberikan tugas tambahan dirumah dan bimbingan soal-soal sehingga keterampilan siswa dalam menyelesaikan soalsoal matematika lebih terasa. Diharapkan kepada para peneliti di bidang pendidikan, dan para matematikawan khususnya agar melakukan penelitian lebih lanjut tentang penggunaan model pembelajaran Problem Based Learning. 


\section{DAFTAR PUSTAKA}

Arikunto. (2006). Dasar-Dasar Evaluasi Pendidikan. Jakarta: Bumi Aksara

Hadijah, H., Nasir, A. M., \& Hasmar, D. H. (2019). Efektivitas Model Problem Based Learning dengan Bantuan Media Animasi pada Materi Bangun Datar Segi Empat terhadap Prestasi Belajar Matematika. In PROSIDING Seminar Nasional FKIP Universitas Muslim Maros (Vol. 1, pp. 151-158).

Hodiyanto. (2017). Eksperimentasi Model Pembelajaran Problem Posing dan Problem Solving dengan Pendekatan PMR Terhadap Prestasi belajar dan Kemampuan
Komunikasi matematis Ditinjau dari Kreativitas Siswa kelas VII SMP Negeri di Kabupaten Sukoharjo. Tesis. Surakarta: UNS.

Rusman. (2013). Model-Model Pembelajaran Mengembangkan profesionalisme. Edisi Kedua. Jakarta : PT Raja Grafindo Persada

Sumunaringtiasih. (2017). Pengaruh Model Problem Based Learning (PBL) Terhadap Kemampuan Komunikasi Matematis Siswa.

Yanti dan Basri. (2017). Pengaruh Model Pembelajaran Problem Based Learning (PBL) Terhadap Motivasi Belajar Siswa. 